\title{
Determination of Mineral Elements and Crude Protein of Eight Medicinal Plants from Central Côte D'ivoire
}

\author{
Brice Kouakou BLA ${ }^{1}$, Jeanne Akissi KOFFI' ${ }^{1}$, Dieudonné \\ Kigbafori SILUE2 ${ }^{2}$ Félix Houphouët YAPI', Joseph Allico \\ DJAMAN 1,3
}

\begin{abstract}
${ }^{1}$ Biochemical Pharmacodynamy Laboratory, Faculty of Biosciences, University of Félix Houphouet Boigny, 22 PO Box 582 Abidjan 22.

${ }^{2}$ Département Environnement et Santé, Centre Suisse de Recherche Scientifique (Côte d'Ivoire), 01 BP 1303 Abidjan 01.

${ }^{3}$ Department of Clinical and Fundamental Biochemistry, Institute Pasteur of Côte d'Ivoire, 01 BP 490 Abidjan 01.
\end{abstract}

\begin{abstract}
An ethnopharmacological survey carried out in the central region of Côte d'Ivoire enabled us select eight medicinal plants used to treat various human diseases. They are :Anthocleista djalonensis, Crossopteryx febrifuga, Harungana madagascariensis, Mangifera indica, Margaritaria discoidea, Pericopsis laxiflora, Spathodea campanulata and Terminalia glaucescens. The purpose of this study is to analyze the elemental content and crude protein and possibly evaluate the link to their therapeutic activities. The analysis by atomic absorption spectrophotometer was used to determine sodium, potassium, iron, magnesium, phosphorus, calcium and zinc contents. The crude proteins were determined using the Kjeldahl method. The values of the mineral elements obtained in the different plants are as follows: Fe (237.46-383.1 ppm) Zn (3.43-33.76 ppm), Ca (17.63-129.05 ppm) $\mathrm{P}$ (23.63-36.06 ppm), Na (103.16-492.63 ppm) K (468.3-754.3 ppm) and Mg (736.3-743.79 ppm). The proportion of the crude proteins obtained was in the range of 5.46 to $12.38 \%$. The possible relationship between these minerals elements found in these plants and its' use as remedies against certain diseases is discussed.
\end{abstract}

Keywords : Central Côte d'Ivoire, crude protein, elemental contents, medicinal plants.

\section{Introduction}

In Côte d'Ivoire (West Africa) many indigenous plants are used as spices, food or medicine. A great number of these plants are traditionally noted for their medical properties (Aké-Assi, 1979a). It has the advantage of being readily available to the people at a considerable lower cost (Cunningham, 1993). The dependence on indigenous medicinal plants for treatment is particularly observed in developing countries where modern medicine is often too expensive therefore out of reach of the majority of the population (Carillon, 2009). The results from several studies showed that native plants are used in the treatment of coughs, hypertension, rheumatism, joint pain, diarrhea, dysentery, stomach problems, diabetes, migraine, hemorrhoids, malaria, snake bites, bleeding, convulsions, schistosomiasis, menstrual pain, filariasis, gonorrhea, infertility, epilepsy and even cancer (Ake-Assi, 1979b). In the course of our study, we carried out survey involving nine traditional healers, in the central region of Cote $d$ Ivoire, where we have been able to identify several medicinal recipes, but 8 in particular have attracted our attention due to their utilization in the treatment of malaria (Bla et al., 2015). They are: Anthocleista djalonensis, Crossopteryx febrifuga, Harungana madagascariensis, Mangifera indica, Margaritaria discoidea, Pericopsis laxiflora, Spathodea campanulata and Terminalia glaucescens. Most of these plants have antiparasitic properties in general and antimalaria in particular (Mustafa et al., 2000, Koné et al., 2005, Traoré et al., 2013). Entire parts of these plants are used by the population to treat to treat several diseases (N'Guessan et al., 2009, Koné et al. 2002). Thus, bark, roots, stems, leaves, leafy branches and fruits are regularly used for medicinal preparations. The therapeutic actions of these preparations total or totum have shown positive

This article is published under the terms of the Creative Commons Attribution License 4.0 Author(s) retain the copyright of this article. Publication rights with Alkhaer Publications.

Published at: http://www.ijsciences.com/pub/issue/2016-02/

DOI: 10.18483/ijSci.946; Online ISSN: 2305-3925; Print ISSN: 2410-4477 
results in many ways thanks to the combined action of the active ingredient, mineral elements and vitamins (Girre, 1997). However among these substances, it is often difficult to highlight the most essential element for treating a given disease. The feature that stands out is that each active ingredient is accompanied by its precursors and metabolites, which may also be active. In addition, an active principle coexists with other active substances as well as mineral elements which are indispensable, for instance by taking part in the enzymatic reactions. Medicinal plants efficacy would therefore be the result of several substances present in varying amounts in the organism each playing a specific role. In this study, we carried out the determination of total protein and mineral elements such as iron, magnesium, zinc, calcium, phosphorus, sodium and potassium. Their choice is justified by their essential biological role played in the body. These minerals have been recognized as indispensable to human life by WHO (Picard, 1975). While proteins are known to play immunostimulatory role (Ezekwe et al., 2001). The aim of our study is to determine in these plants, the levels of crude protein and essential minerals and possibly look for the link between these elements and, thus the active substances and the pharmacological effects observed.

\section{Materials and Methods \\ Plant Materials}

The experimental species were collected from Moronou Village in Toumodi area, Central Côte d'Ivoire. The plant materials (leaves and bark) were identified and authenticated by Mr. Assi Jean of National of Floristic Centre of University of Felix Houphouet Boigny (Abidjan). The samples were airdried for 15 days and milled into powder with the aid of an electrical grinder and finally stored in airtight bottles before analysis.

\section{Mineral Analysis and Determination of Crude Proteins}

The major elements, comprising calcium, phosphorus, sodium, potassium, magnesium and trace elements (iron and zinc) were determined according to the method of Shahidi et al. (1999). The ground plant samples were sieved with a $2 \mathrm{~mm}$ rubber sieve and $2 \mathrm{~g}$ of each of the plant samples were weighed and subjected to dry ashing in a well-cleaned porcelain crucible at $550{ }^{\circ} \mathrm{C}$ in a muffle furnace. The resultant ash was dissolved in $5 \mathrm{~mL}$ of $\mathrm{HNO}_{3} / \mathrm{HCl} / \mathrm{H}_{2} \mathrm{O}(1: 2: 3)$ and heated gently on a hot plate until brown fumes disappeared. To the remaining material in each crucible, $5 \mathrm{ml}$ of deionized water was added and heated until a colourless solution was obtained. The mineral solution in each crucible was transferred into a 100 $\mathrm{ml}$ volumetric flask by filtration through a whatman filter paper and the volume was made to the mark with deionized water. This solution was used for elemental analysis by atomic absorption spectrophotometer. A $10 \mathrm{~cm}$-long cell was used and concentration of each element in the sample was calculated on percentage of dry matter. Phosphorus content of the digest was determined colorimetrically according to the method described by Nahapetian and Bassiri (1975). To $0.5 \mathrm{~mL}$ of the diluted digest, $4 \mathrm{~mL}$ of demineralised water, $3 \mathrm{ml}$ of $0.75 \mathrm{M} \mathrm{H}_{2} \mathrm{SO}_{4}, 0.4$ $\mathrm{mL}$ of $10 \%\left(\mathrm{NH}_{4}\right)_{6} \mathrm{MO}_{7} \mathrm{O}_{24} .4 \mathrm{H}_{2} \mathrm{O}$ and $0.4 \mathrm{~mL}$ of $2 \%$ $(\mathrm{w} / \mathrm{v})$ ascorbic acid were added and mixed. The solution was allowed to stand for $20 \mathrm{~min}$ and absorbance readings were recorded at $660 \mathrm{~nm}$. The content of phosphorus in the extract was determined. The Kjeldahl method was used to estimate crude protein in plant materials (Allen, 1989).

\section{Statistical Analysis}

All the analyses were performed in triplicate and data were analyzed using EXCELL 2007. Data were expressed as mean \pm standard deviation (SD).

\section{Results}

Results of mineral content in eight medicinal plants are given in table 1 and shown in figure 1 to 7, while the results of crude protein summarized in table 2 .

\section{Discussion \\ Iron}

The range of $\mathrm{Fe}$ in the studied plants was high with a minimum of $237.46 \mathrm{ppm}$ in $M$. discoidea and maximum of $383.1 \mathrm{ppm}$ in $C$. febrifuga (Table 1 and Figure 1). The maximum tolerable level for cattle was suggested as 1000 ppm by National Research Council (1984). The permissible limit set by FAO/WHO (1984) in edible plants was $20 \mathrm{ppm}$. After comparison, metal limit in the studied medicinal plants with those proposed by FAO/WHO (1984) it is found that all plants accumulate Fe above this limit. However, for medicinal plants the WHO (2005) limits not yet been established for Fe. Sheded et al. (2006) reported that the range of $\mathrm{Fe}$ in their study was between $261 \mathrm{ppm}$ to $1239 \mathrm{ppm}$ in selective medicinal plants of Egypt. $\mathrm{Fe}$ is necessary for the formation haemoglobin and also plays an important role in oxygen and electron transfer in human body (Kaya and Incekara, 2000).

\footnotetext{
Magnesium

Magnesium deficiency in humans caused muscle spasms, and has been associated with a high blood pressure, many cardiovascular diseases, diabetes and osteoporosis. The necessary daily intake is 350 $\mathrm{mg}$ /day for men and $300 \mathrm{mg} /$ day for women (Mogos, 1997). The values obtained for Magnesium in analyzed medicinal plants ranged between $0.718-$ $0.107 \%$. The highest content was measured in $M$. discoidea (743.79 ppm) and the smallest in $S$. campanulata (73.63 ppm) (Table 1 and Figure 2).
} 


\section{Zinc}

The content of $\mathrm{Zn}$ ranged between $3.43 \mathrm{ppm}$ in $H$. madagascariensis and $33.76 \mathrm{ppm}$ in A. djalonensis (Table 1 and Figure 3). The maximum tolerable zinc level has been set at $500 \mathrm{ppm}$ for cattle and $300 \mathrm{ppm}$ for sheep (National Research Council, 1984). The permissible limit set by FAO/WHO (1984) in edible plants was $27.4 \mathrm{ppm}$. After comparison, metal limit in the studied medicinal plants with those proposed by FAO/WHO (1984) it is found that all studied plants are below this limit excepted A. djalonensis. The zinc content could mean that the plants can play a valuable role in management of diabetes, which results for including insulin malfunctioning. Zinc is essential for the production of insulin (Okwu and Morah, 2004).

\section{Calcium}

Calcium deficiency for a long time is responsible for osteoporosis, when the bones are deteriorated and increased the risk of fractures. The necessary daily intake is between 350 and $1100 \mathrm{mg}$ /day (Mogos, 1997). In analyzed medicinal plants, the calcium contents varied between 17.63-129.05 ppm. The highest calcium content was obtained for $M$. discoidea (129.05 ppm), followed by $H$. madagascariensis $(85.76 \mathrm{ppm})$ and $P$. laxiflora (74.54 ppm). The smaller calcium concentration was determinate for $T$. glaucescens (74.54 ppm) (Table 1 and Figure 4).

\section{Phosphorus}

Table shows that the concentration of phosphorus ranged between $23.63 \mathrm{ppm}$ in $P$. laxiflora and 36.06 ppm in T. glaucescens (Table 1 and Figure 5). All examined samples were above the deficiency level of phosphorus which is below 1.5 ppm (Allen, 1989; Al-Jaloud et al., 1994). Phosphorous maintain blood sugar level, normal heart contraction dependent on phosphorous also important for normal cell growth and repair, needed for bone growth, kidney function and cell growth. It plays important role in maintaining body's acid-alkaline balance (Johns and Duquette, 1991).

\section{Sodium}

The lowest content of $\mathrm{Na}$ that is 103.16 ppm was in T. glaucescens and maximum concentration was estimated as $492.63 \mathrm{ppm}$ in $M$. indima (Table 1 and Figure 6). All plants showed low accumulation. Sodium is a major cation of extracellular fluid and therefore plays a central role in the maintenance of water balance and osmotic pressure in various fluid compartments (Tietz et al., 2001). Ikekpeazu et al. (2010) have shown that malaria infection leads to a reduction in the levels of both serum $\mathrm{Na}^{+}$and $\mathrm{K}^{+}$.

\section{Potassium}

The range of $\mathrm{K}$ varied between $468,3 \mathrm{ppm}$ in $S$. campanulata and 754,3 ppm in T. glaucescens (Table 1 and Figure 7). All the studied plant show high $\mathrm{K}$ contents and our results coincided with the previous studies on medicinal herbs (Badri and Hamed, 2000; Ozcan and Akbulut, 2007). Contrarily, $\mathrm{K}^{+}$is a major intracellular cation, having an average cellular concentration in tissue cells of $150 \mathrm{mM}$ (Kaplan et al., 1995). Besides water balance, these electrolytes play an important role in maintenance of $\mathrm{pH}$, regulation of heart and muscle function, electron transfer reactions as well as serving as cofactors for enzymes (Tietz et al., 2001).

\section{Crude protein}

The minimum crude protein was $5.46 \%$ in $M$. indica and the maximum was $12.38 \%$ in P. laxiflora (Table $2)$. Our concentration values are relatively low compared to Atangwho et al. (2009), where concentrations were found in an amount ranging from 13.42 to $25.55 \%$ in Azadirachta indica, Vernonia amygdalina and Gongronema latifolium. All these three plants have anti-diabetic properties (NimeniboUadia, 2003).

\section{Conclusion}

The mineralization by calcination in atomic mass spectrometry method has helped to identified the content level of $\mathrm{Na}, \mathrm{K}, \mathrm{Fe}, \mathrm{Mg}, \mathrm{P}, \mathrm{Ca}$ and $\mathrm{Zn}$ in eight medicinal plants used in traditional medicine to treat malaria in Côte d'Ivoire. Among these minerals, macronutrients such as $\mathrm{Mg}, \mathrm{Ca}$ and $\mathrm{K}$ are present in good quantity in most plants. The presence of these essential mineral elements coupled with phytochemicals (steroids, terpenes and flavonoids) in these plants may have contributed to their potential usage as medicinal plants highly esteemed in some parts of the tropical world for malarial treatment.

\section{Acknowledgement}

We sincerely give thanks to traditional healers and village chiefs of Moronou for their contribution to the success of the entnobotanical part of this work. Our thanks also go to Mr. Jean ASSI Yapo, at the National Floristic Centre for the identification of our plants.

\section{Conflict of interest}

The authors have none to declare.

\section{References}

1. Aké-Assi. L. (1979a). La Préservation des espèces végétales pour la santé humaine en Afrique au sud du Sahara. Communications Scientifiques présentées au troisième Symposium Interafricain OUA/CSTR sur la pharmacopée traditionnelle et les plantes médicinales africaines, Abidjan, 25-29 septembre 1979, p 27-31.

2. Aké-Assi. L. (1979b). Sept années d'investigation sur la Phytothérapie en Cóte d'Ivoire. Séminaire sur la Pharmacopée Africaine et la Médecine Traditionnelle, INFOSEC, Cotonou. 16-28 avril 1979, pp. 5.

3. Al-Jaloud, A.A., Chaudhary, S.A., Bashour, I.I., Qureshi, S. \& Al-Shaghitti, A. (1994). Nutrient evaluation of some arid range plants in Saud Arabia. J.Arid. Env. 28: 299-311. 
4. Allen, S.E. (1989). Chemical Analysis of EcologicalMaterials. Oxford: Blackwell Scientific Publications. 368 pp.

5. Atangwho I. J., Ebong P. E., Eyong E. U., Williams I. O., Eteng M. U. and Egbung G. E. (2009). Comparative chemical composition of leaves of some antidiabetic medicinal plants: Azadirachta indica, Vernonia amygdalina and Gongronema latifolium. Afr. J. Biotechnol. 8 (18): 4685-4689.

6. Badri M.A. and Hamed A.I. (2000). Nutrient value of plants in an extremely arid environment (Wadi Allaqi biosphere reserve, Egypt). J. Arid Env. 44: 347-356.

7. Bla K.B., Trébissou J.N.D., Bidié P., Assi Y.J., Zirihi-Guédé N., Djaman A.J. (2015). Etude ethnopharmacologique des plantes antipaludiques utilisées chez les Baoulé-N'gban de Toumodi dans le Centre de la Côte d'Ivoire. J. Apll. Biosci. $85: 7775-7783$.

8. Carillon A, 2009. Place de la phytothérapie dans les systèmes de santé au XXIè s. Conférence SIPAM-Djerba, Mars 2009.

9. Cunningham A.B. 1993. Setting priorities at the interface between conservation and primary health care, People and Plants Working Paper 1. Paris: UNESCO; 1993.

10. Ezekwe, M.O., Besong S.A. and Igbokwe P.E. (2001). Beneficial influence of purslane and waterleaf supplement to Human, FASEB J., 16: A639.

11. FAO/WHO (1984). Contaminants. In Codex Alimentarius, vol. XVII, Edition 1. FAO/WHO, Codex Alimentarius Commision, Rome

12. Girre L. (1997). Traditions et propriétés des plantes médicinales, Histoire de la pharmacopée, Privat, éditions de santé, Toulouse (FR), 1997.

13. Ikekpeazu E.J., Neboh E.E., Aguchime N.C., Maduka I.C., Anyanwu E.G. (2010). Malaria parasitaemia: effect on serum sodium and potassium levels. Biol Med. 2 (2): 20-25, 2010.

14. Johns T. and Duquette M. (1991). Deficiency of phosphorus in man. Am. J. Clin. Nutr. 53: 448-456.

15. Kaya I. and Incekara N. (2000). Contents of some wild plants species consumed as food in Aegean region. J. Turkish Weed Sci. 3: 56-64.

16. Koné M.K., Atindehou K., Traoré D. \& Betschart B. (2005). Anthelmintic Activity of Medicinal Plants Used in Northern Côte d'Ivoire Against Intestinal Helminthiasis. Pharm. Biol. 43 (1): $72-78$

17. Koné M.W., Kamanzi A. K., Traoré D. (2002). Plantes et médecine traditionnelle dans la région de Ferkessédougou (Côte d'Ivoire). Ann.Bot. Afr. Ouest $2: 13-23$.
18. Mogos V.T., Alimentatia in bolile de nutritie si metabolism, vol. 1, Editura Didactica si Pedagogica, R.A., Bucuresti, 1997, p. 356, 391, 409, 422.

19. Mustofa, Valentin A., Benoit-Vical F., Pélissier Y., KonéBamba D., Mallié M. (2000). Antiplasmodial activity of plant extracts used in West African traditional medicine. J. Ethnopharmacol. 73 (1-2) : 145-51.

20. N'Guessan K., Tra Bi F.H., Koné M.W. (2009). Étude ethnopharmacologique de plantes antipaludiques utilisées en médecine traditionnelle chez les Abbey et Krobou d'Agboville (Côte d'Ivoire). Ethnopharmacologia, $44: 42$ 50.

21. National Research Concil (NRC) 1984. Nutrient requirement for beef cattle, $6^{\text {th }}$ Rev ed Nutrient requirement of domestic animals. Natl Acad Sci Wash (4): 421-427.

22. Nimenibo-Uadia R. (2003). Effect of Vernonia amygdalina in alloxan- induced diabetic albino rats. J. Med. Lab. Sci. 12(1): 25-31.

23. Okwu D.E. and Morah F.N. (2004). Mineral and nutritive value of dennrttia tripelata fruits. Fruits, 59: 437-442.

24. Ozcan M.M. and Akbulut M. (2007). Estimation of minerals, nitrates and nitrite content of medicinal and aromatic plants used as spices, condiments and herbal tea. Food Chem. 106:852-858.

25. Picard H. Utilisation thérapeutique des oligo-éléments . Ed. Maloine, Paris (1975).

26. Shahidi F., Chavan U.D., Bal A.K., Mckenzie D.B. (1999). Chemical Composition of Beach pea (Lathyrus maritimus L). Plant parts. Food Chem. 64: 39-44.

27. Sheded G.M., Pulford I.D., Hamed I.A. (2006). Presence of major and trace elements in seven medicinal plants growing in the South-Eastern Desert. Egypt. J. Arid. Env. 66: 210217.

28. Tietz N., Pruden L.E., Andersen S. (2001). Electrolytes. In: Tietz fundamentals of clinical chemistry, 5th ed. WB Saunders Company, Philadelphia, pp 723-740.

29. Traoré M.S., Baldé M.A., Diallo M.S., Baldé E.S., Diané S., Camara A., Diallo A., Balde A., Keïta A., Keita S.M., Oularé K., Magassouba F.B., Diakité I., Diallo A., Pieters L., Baldé A.M. (2013). Ethnobotanical survey on medicinal plants used by Guinean traditional healers in the treatment of malaria. J. Ethnopharmacol. 150 (3): 1145-53.

30. WHO (2005). Quality Control Method for Medicinal Plant Materials, Revised, Geneva.

Table 1: Concentration (ppm®) of major and trace elements of studies plants

\begin{tabular}{|c|c|c|c|c|c|c|c|}
\hline Plant & $\mathrm{Fe}$ & $\mathrm{Mg}$ & $\mathrm{Zn}$ & $\mathrm{Ca}$ & $\mathrm{P}$ & $\mathrm{Na}$ & $\mathrm{K}$ \\
\hline A. djalonensis & $350,43 \pm 8,70$ & $194,21 \pm 3,26$ & $33,76 \pm 2,25$ & $20,03 \pm 2,88$ & $31,6 \pm 0,20$ & $173,73 \pm 0,68$ & $668,14 \pm 1,80$ \\
\hline C. febrifuga & $383,10 \pm 6,48$ & $244,81 \pm 0,90$ & $18,83 \pm 0,47$ & $38,07 \pm 1,69$ & $29,73 \pm 0,45$ & $175 \pm 2,78$ & $627,64 \pm 1,32$ \\
\hline H. madagascariensis & $241,46 \pm 5,12$ & $408,21 \pm 1,66$ & $3,43 \pm 0,32$ & $85,76 \pm 2,77$ & $25,63 \pm 0,28$ & $285 \pm 2,29$ & $667,46 \pm 1,75$ \\
\hline M. indica & $248,33 \pm 5,93$ & $105,88 \pm 2,78$ & $5,43 \pm 0,75$ & $39,54 \pm 4,69$ & $30,76 \pm 0,40$ & $492,63 \pm 0,70$ & $648,97 \pm 0,76$ \\
\hline M. discoidea & $237,46 \pm 5,49$ & $743,79 \pm 4,30$ & $12,33 \pm 0,66$ & $129,05 \pm 5,61$ & $27,96 \pm 0,90$ & $297,43 \pm 1,50$ & $546,30 \pm 3,32$ \\
\hline P. laxiflora & $251,73 \pm 5,39$ & $704,13 \pm 4,58$ & $13,56 \pm 0,97$ & $74,54 \pm 2,40$ & $23,63 \pm 0,60$ & $153,16 \pm 2,02$ & $743,40 \pm 1,91$ \\
\hline S. campanulata & $277,10 \pm 4,55$ & $73,63 \pm 1,98$ & $17,8 \pm 0,65$ & $71,6 \pm 1,22$ & $33,56 \pm 0,35$ & $141,83 \pm 1,89$ & $468,30 \pm 0,76$ \\
\hline T. glaucescens & $344,93 \pm 6,10$ & $154,46 \pm 2,15$ & $12,16 \pm 0,50$ & $17,63 \pm 1,60$ & $36,06 \pm 1,50$ & $103,16 \pm 3,32$ & $754,30 \pm 4,01$ \\
\hline
\end{tabular}

( ) : Average concentration of element \pm standard deviation $(\mathrm{n}=3)(\mathrm{mg} / \mathrm{Kg})$ 
Table 2: Concentration of crude protein of studied plants

\begin{tabular}{ll}
\hline Plant & Crude proteins (\%) \\
\hline Anthocleista djalonensis & 10.72 \\
Crossopteryx febrifuga & 9.46 \\
Harungana madagascariensis & 7.43 \\
Mangifera indica & 5.46 \\
Margaritaria discoidea & $\mathrm{ND}$ \\
Pericopsis laxiflora & 12.38 \\
Spathodea campanulata & $\mathrm{ND}$ \\
Terminalia glaucescens & 10.15 \\
\hline
\end{tabular}

ND : undetermined data

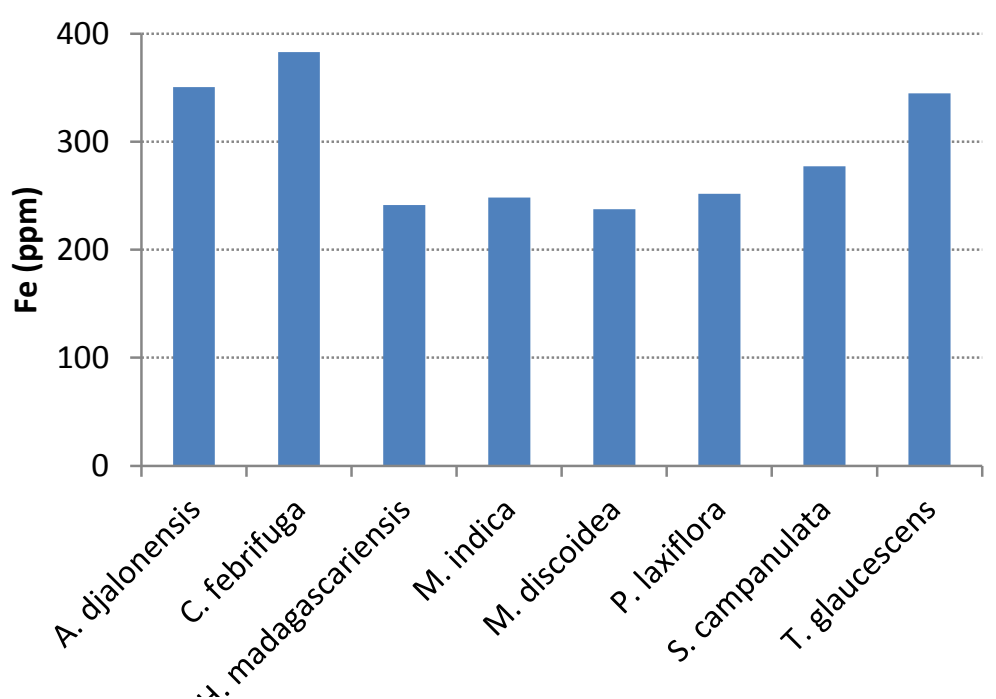

Figure 1: Concentration of iron in studied plants

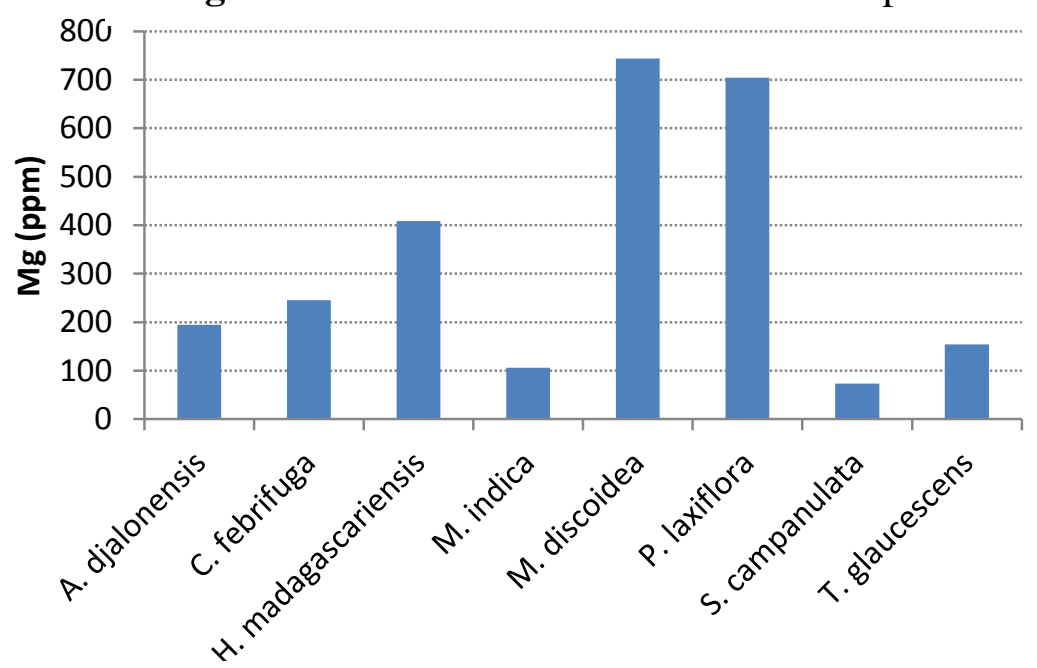

Figure 2: Concentration of magnesium in studied plants 


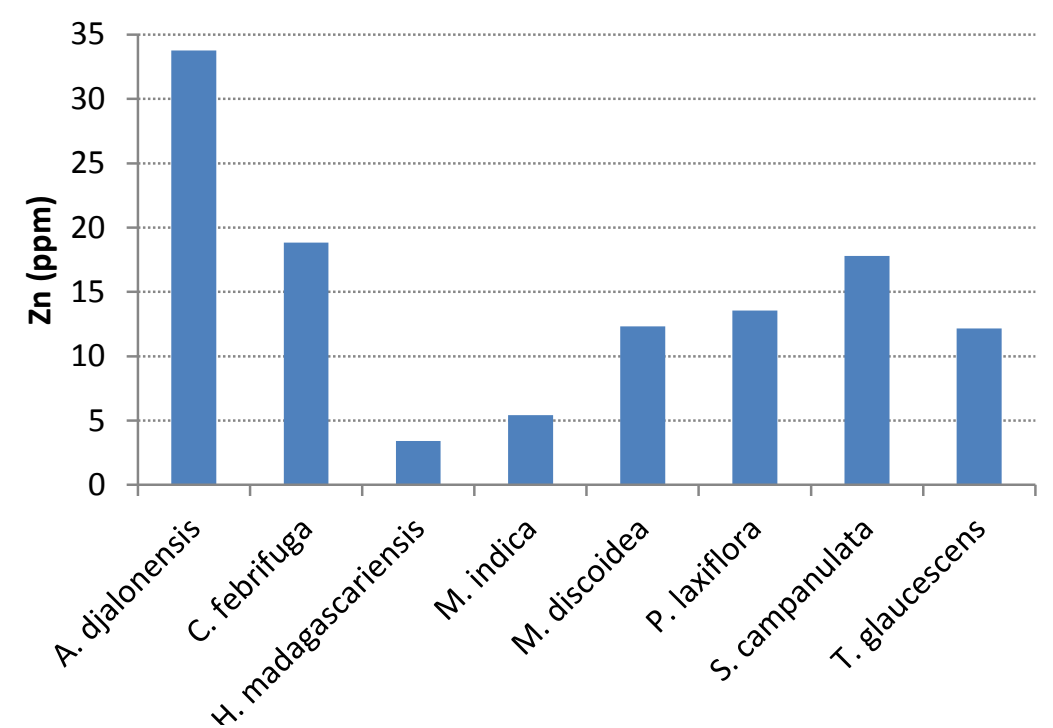

Figure 3: Concentration of zinc in studied plants

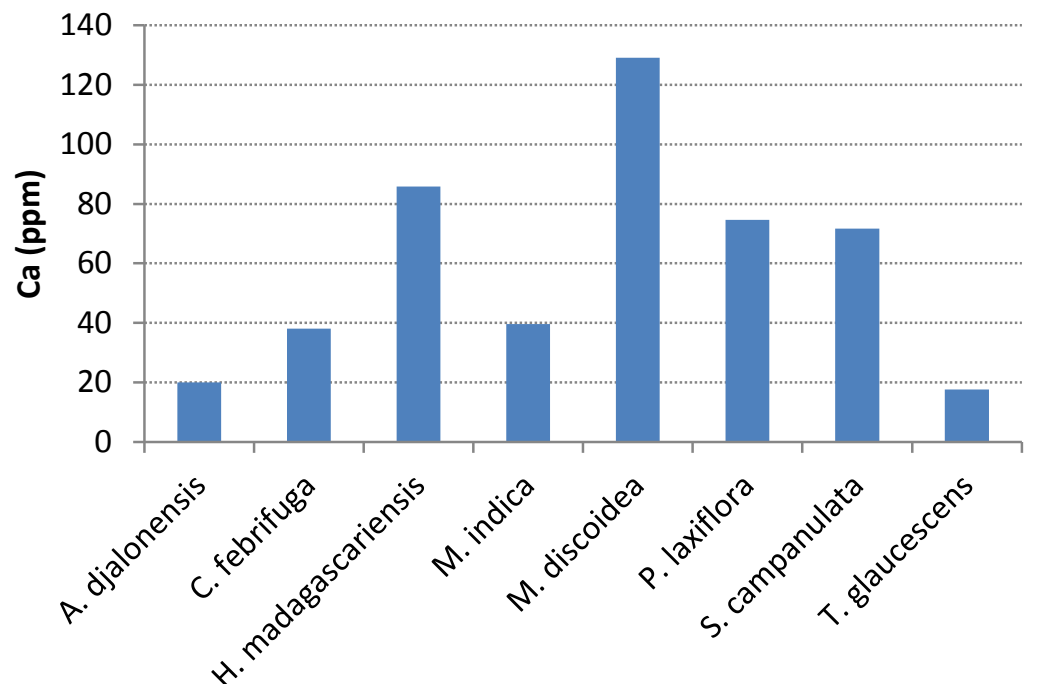

Figure 4: Concentration of calcium in studied plants

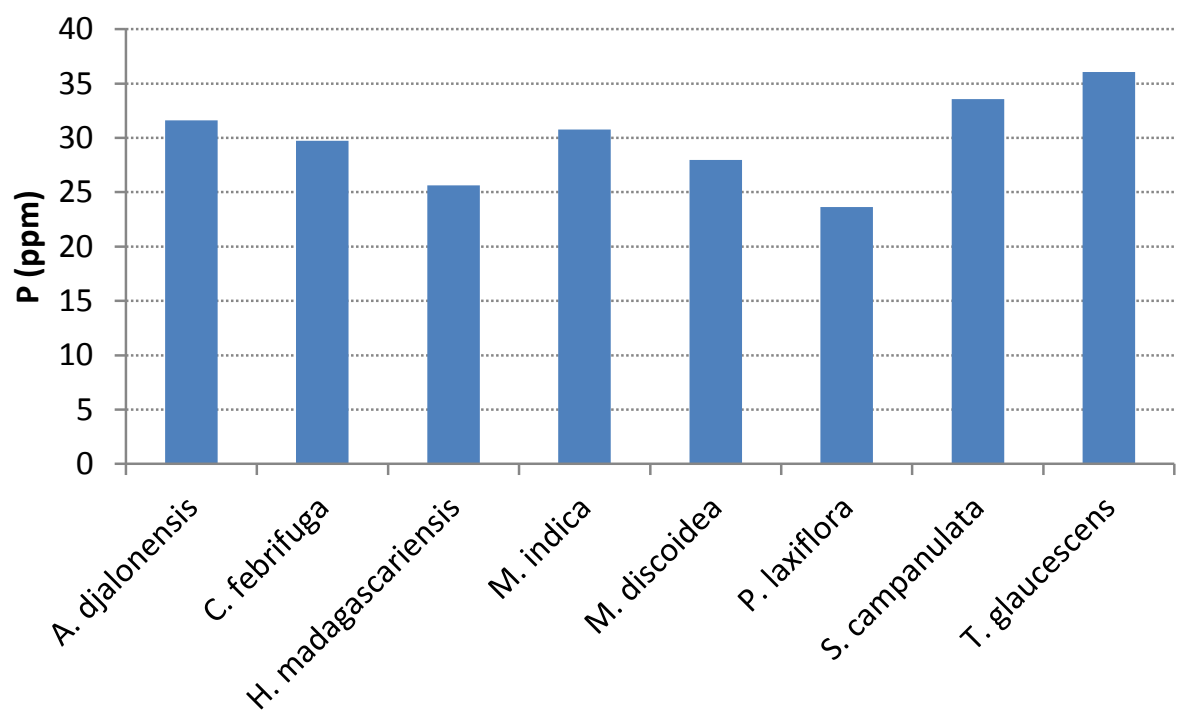

Figure 5: Concentration of phosphorus in studied plants 


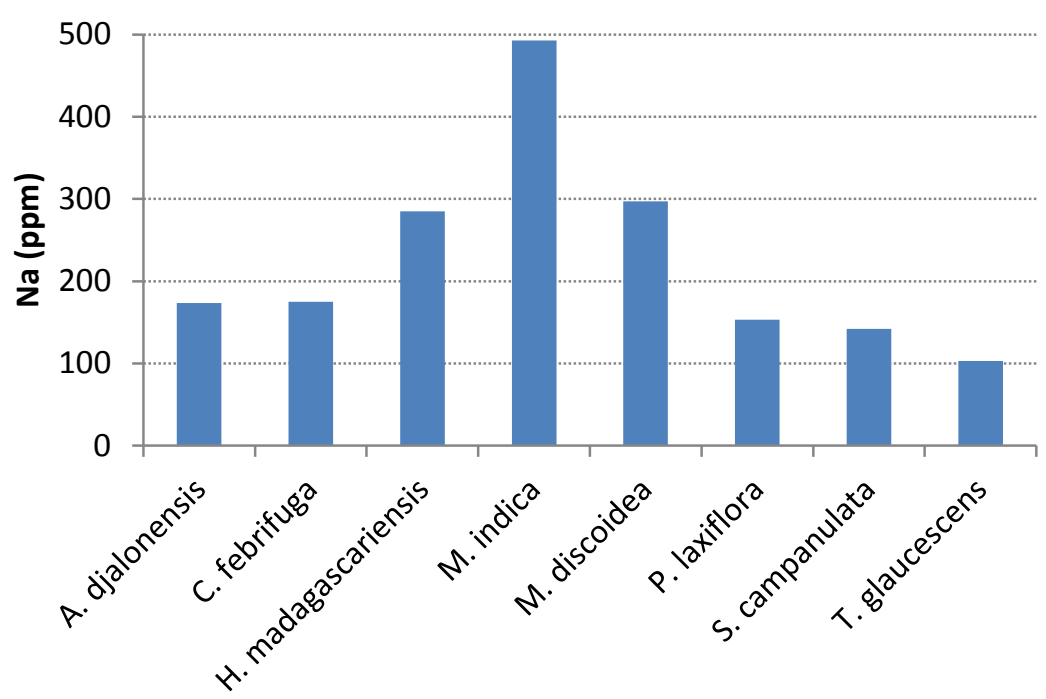

800 Figure 6: Concentration of sodium in studied plants

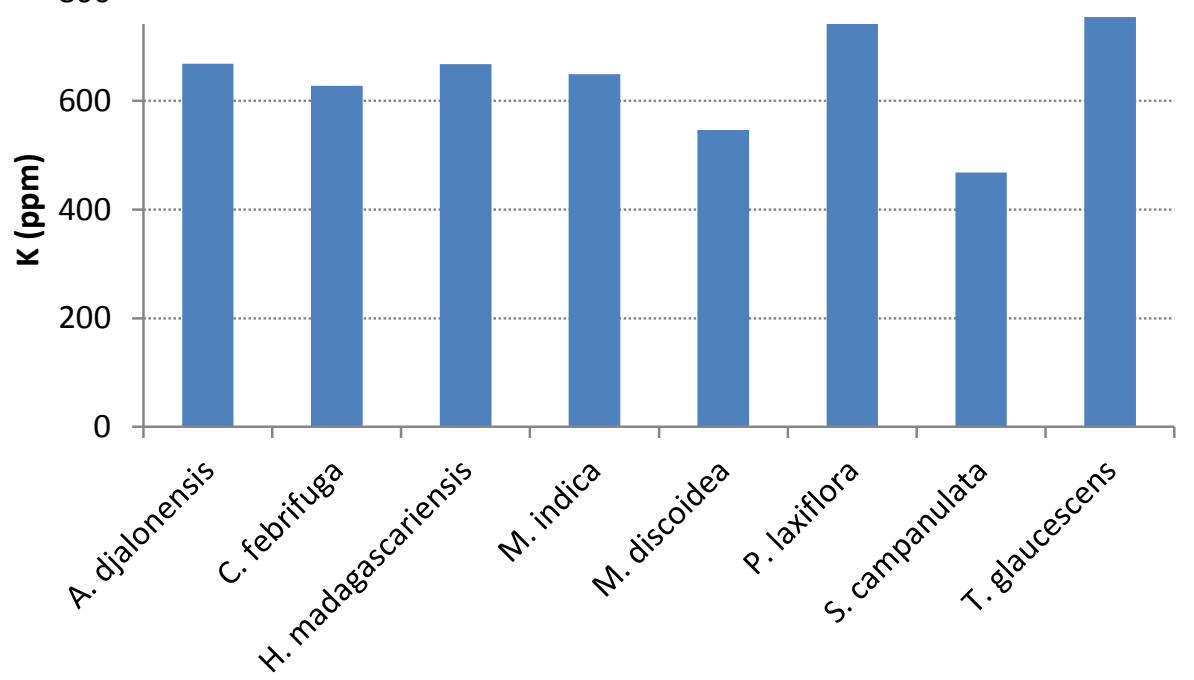

Figure 7: Concentration of potassium in studied plants 